\title{
Steer and Vegetation Response to Short Duration and Con- tinuous Grazing
}

\author{
J.S. PITTS AND F.C. BRYANT
}

\section{Abstract}

Comparisons were made over a 4-year period between 1-herd, 16-pasture short duration grazing (SDG) and continuous grazing (CG) on the Texas High Plains. Animal performance, vegetation response, and diet quality were evaluated. Stocking rate on SDG was equal to that on $\mathrm{CG}$ the first year $(13.3 \mathrm{ha} / \mathrm{AU})$, double that on CG in the second year, and 1.5 times that on CG the third and fourth years. Average daily gain (ADG) of steers was the same $(0.33 \mathrm{~kg} / \mathrm{day})$ between SDG and CG the first year. When stocking was doubled on SDG the second year, steers on SDG gained 0.15 $\mathrm{kg} / \mathrm{day}$ compared to $0.25 \mathrm{~kg} / \mathrm{day}$ under $\mathrm{CG}$. In the third and fourth years, with stocking under SDG at 1.5 times that on $C G$, gains were similar. Standing crop biomass on SDG fell below that on CG after 1 year of graxing. In the second year standing crop was greater $(P<0.05)$ on SDG than on $C G$, but in years 3 and 4 , standing crop on the SDG was leas than on CG. Changes in species composition were the same on both CG and SDG. Steer diet composition and quality were evaluated during the growing season (May to October) of year 4. Steers on SDG consumed $15 \%$ more forbs (39\% vs $24 \%$ ) than steers on CG. No differences $(P>0.05)$ between CG and SDG were obaerved for dietary crude protein or in vitro digeatible organic matter. SDG did not improve animal performance, diet quality, or forage availability over CG when evaluated over 4 years.

Grazing systems have been developed as a means of increasing rangeland productivity through increased carrying capacity. Heitschmidt et al. (1982b) described 3 means of increasing carrying capacity, (1) increased forage quality, (2) increased forage quantity, and (3) increased efficiency of harvest. Short duration grazing (SDG) has been proposed as a system which could offer benefits in all 3 of these areas.

Since its introduction, SDG has been a subject of great controversy. Three-fold increases in stocking have been reported in Africa (Nicholas 1976). Savory and Parsons (1980) stated that carrying capacity would increase rapidly under the "Savory Grazing Method" in most instances. In Texas, Heitschmidt et al. (1982a) showed increases in forage production were possible using a 10-pasture SDG system. Not all reports on SDG have been favorable, however. After 3 years under SDG in Africa, Denny et al. (1977) found no improvement in range condition and there was no indication that carrying capacity could be increased. Denny and Barnes (1977) also reported that animal performance would decrease with SDG systems. In contrast, Heitschmid tet al. (1982b) showed no differences in animal performance between SDG and CG, and Nicholas (1976) indicated that animal performance may even be enhanced under SDG.

It appears that response to SDG may vary depending upon climatic condition and vegetation type. The objectives of this study were to compare SDG and continuous year-long grazing (CG) on poor condition short grass range in terms of (1) animal perfor-

At the time of this research, Pitts was a graduate research assistant and Bryant was associate professor, Department of Range and Wildlife Management, Texas Tech University. Lubbock 79409. Pitts is currently superintendent, Texas Tech Experimental Ranch, Justiceburg 79330. This research was supported in part by the Noxious Brush and Weed Control Programs, Texas Tech University, and the USAID, Small Ruminant Collaborative Research Support Program, under grant DSAN/XII-G0049. This is Technical Article T-9-452 of the College of Agricultural Sciences, Texas Tech University.

Manuscript accepted 14 May 1987 mance, (2) forage dynamics, and (3) diet quality.

\section{Methods and Procedures}

The study site was located in Lubbock County, Texas, on the Texas Tech University campus. At the initiation of the study, the area was considered a poor condition native shortgrass range site on an Amarillo fine sandy loam soil. Dominant grasses on the site were Bouteloua gracilis, Buchloe dactyloides, Panicum obtusum, Sporobolus cryptandrus, Aristida purpurea, and Bothriochloa saccharoides. Major forbs were Kochia scoparia, Zinnia grandiflora, Spharalcea coccinea, and Kuhnia sp. There also was a heavy infestation of Xanthocephalum sarothrae and Prosopis glandulosa.

The climate is warm-temperate and continental with an average annual precipitation of $40 \mathrm{~cm}$. Precipitation occurs mainly in the spring and late summer months. Temperature ranges from $+40^{\circ} \mathrm{C}$ to $-25^{\circ} \mathrm{C}$ with a frost-free growing season of 200 days. Mean elevation is $960 \mathrm{~m}$. (SCS 1979).

Two grazing case studies with identical yearlong stocking rates were initiated in May 1979. About 32 ha was stocked continuously yearlong with 4 steers at a rate of $13.3 \mathrm{ha} / \mathrm{AU}$. Steers were considered 0.6 AU. The CG pasture remained at the same rate of stocking throughout the 4-year study. Adjacent to CG, a 1-herd, 16-pasture, short duration grazing system was applied to an additional 48 ha. During the first year (May 1979 to March 1980), 6 steers were used to stock equal to $\mathrm{CG}$ at $13.3 \mathrm{ha} / \mathrm{AU}$. In April 1980, stocking rate on SDG was increased to $6.7 \mathrm{ha} / \mathrm{AU}$ using 12 steers and remained at that rate until April 1981. In May 1981, the stocking rate under SDG was reduced to 8.9 ha/ AU using 9 steers and remained at that rate until November 1982, when the animal response study ceased. Each pasture under SDG was approximately 3 ha. Grazing period per pasture under SDG was 2 to 7 days followed by 30 to 60 days rest (Savory and Parsons 1980).

New steers were obtained each year of the study. The steers were purchased in April or May weighing 170 to $180 \mathrm{~kg}$ and sold the following year weighing 270 to $280 \mathrm{~kg}$. Steers were randomly allotted to CG or SDG and weighed monthly after being fasted overnight. Because of a lack of replication, statistical differences between CG and SDG were detected using " $t$ " tests for each weighing period and for each year of the study (Steel and Torrie 1960). Animal variance within case studies was used (Conniffe 1976).

Standing crop of herbaceous material was determined in May 1979 before grazing started and in May and October 1980; February, May, August, and December 1981; March, May, August, and November 1982; May 1983. A transect was established in each of the 16 SDG pastures, and 7 plots were clipped randomly along each transect. Two transects were established in the CG pasture and 20 plots were clipped along each. Plot area was $0.25 \mathrm{~m}^{2}$. Grasses were clipped to ground level by species, air dried in a forced air oven at $55^{\circ} \mathrm{C}$, and weighed. Forbs were clipped as a composite group, oven dried, and weighed. Differences between case studies were analyzed using " $t$ " tests for each sampling date by grass and forbs as composite groups (Steel and Torrie 1960). Comparisons within CG and SDG for differences between years were analyzed using data from each May sampling. Differences were detected using Duncan's new multiple range test (Steel and Torrie 1960).

Esophageal collections from 2 fistulated steers each on CG and 
SDG pastures were taken for a 6-day period every 18 days from May to November 1982 yielding 12 samples/treatment/collection period. Between collection periods, experimental animals were maintained on an adjacent area of similar vegetation. The 6-day sampling periods on SDG occurred when pastures 6 and 7 , and 15 and 16 were being grazed by the intact herd. Six-day collections on the CG pasture occurred on the same days as on SDG.

Botanical composition of the esophageal samples was determined using micro-histological procedures (Sparks and Malechek 1968). Statistical analyses were not conducted on these samples. Samples were chemically analyzed, in duplicate, for percent nitrogen, later converted to crude protein, using micro-Kjeldahl procedures (A.O.A.C. 1970) and for in vitro digestible organic matter (Van Soest 1970). Chemical constituents of diets were analyzed statistically using analysis of variance. Differences at 0.05 were evaluated using Tukey's test for mean separation (Steel and Torrie 1960).

\section{Results}

\section{Steer Gains and Standing Crop \\ First Year}

During the first year of the study (May 1979 to April 1980), both $\mathrm{CG}$ and SDG were stocked at an equal rate (13.3 ha/ $\mathrm{AU} / \mathrm{yr})$. Average daily gains (ADG) for the year were also the same $(P>0.05)$ at $0.33 \mathrm{~kg} /$ day (Table 1$)$.

Table 1. Average daily gain (ADG) and total gain from steers under short duration and continuous grazing in Lubbock County, Texas, 1979 to 1982.

\begin{tabular}{|c|c|c|c|c|}
\hline \multirow[b]{2}{*}{ Period } & \multicolumn{2}{|c|}{$\mathrm{ADG}, \mathrm{kg}$} & \multicolumn{2}{|c|}{ Total gain, $\mathrm{kg} / \mathrm{ha}$} \\
\hline & SDG & CG & SDG & CG \\
\hline $\begin{array}{l}5 / 79-4 / 80 \\
4 / 80-3 / 81 \\
5 / 81-4 / 82 \\
4 / 82-11 / 82\end{array}$ & $\begin{array}{l}0.33 \\
0.15 \\
0.33 \\
0.55 \\
\end{array}$ & $\begin{array}{l}0.33 \\
0.25 \\
0.37 \\
0.61 \\
\end{array}$ & $\begin{array}{l}15.0 \\
13.7 \\
22.6 \\
22.5 \\
\end{array}$ & $\begin{array}{l}15.0 \\
11.4 \\
16.9^{*} \\
16.6^{*} \\
\end{array}$ \\
\hline Mean & 0.34 & 0.39 & 18.5 & 15.0 \\
\hline
\end{tabular}

*Significant between case studies at $P<0.05$.

Initial total standing crops were similar for both treatments prior to grazing in May 1979. Although, there were no differences between CG and SDG in standing crop of major grass species, biomass of minor grass species, composited and weighed as a group, was greater $(P<0.05)$ under SDG compared with CG. These grasses were $10 \%$ of the total standing crop on SDG and less than $1 \%$ of CG standing crop. Differences in standing crop biomass did not seem to affect ADG. On CG, standing crop doubled ( $204 \mathrm{~kg} / \mathrm{ha}$ $v s 106 \mathrm{~kg} / \mathrm{ha}$ ) over initial clippings by the end of the first year, while standing crop remained the same (111 kg/ha vs $106 \mathrm{~kg} / \mathrm{ha}$ ) under SDG (Fig. 1).

Although there were no differences $(P>0.05)$ between $C G$ and SDG in total standing crop of grasses after 1 year, biomass of Sporobolus cryptandrus on the CG pasture was greater $(P<0.05)$ than on SDG (Table 2). Either steers under SDG selected more heavily for this species than those on the CG pasture, reducing standing crop, or SDG did not allow easy establishment of this species. There were no differences between CG and SDG in standing crop of forbs after 1 year of grazing (Fig. 1).

\section{Second Year}

Stocking rates were doubled (6.7 ha/AU) on SDG during the second year (April 1980 to March 1981). Steers under SDG did not gain as well as steers on CG $(0.15 \mathrm{~kg} /$ day compared to $0.25 \mathrm{~kg} /$ day, respectively; Table 1), but the difference was not significant $(P>0.05)$.

The second year of the study was a drought year. Grass standing crop was greater $(P<0.05)$ under SDG compared to CG. Greater biomass of Bothriochloa saccharoides and Aristida purpurea, 2
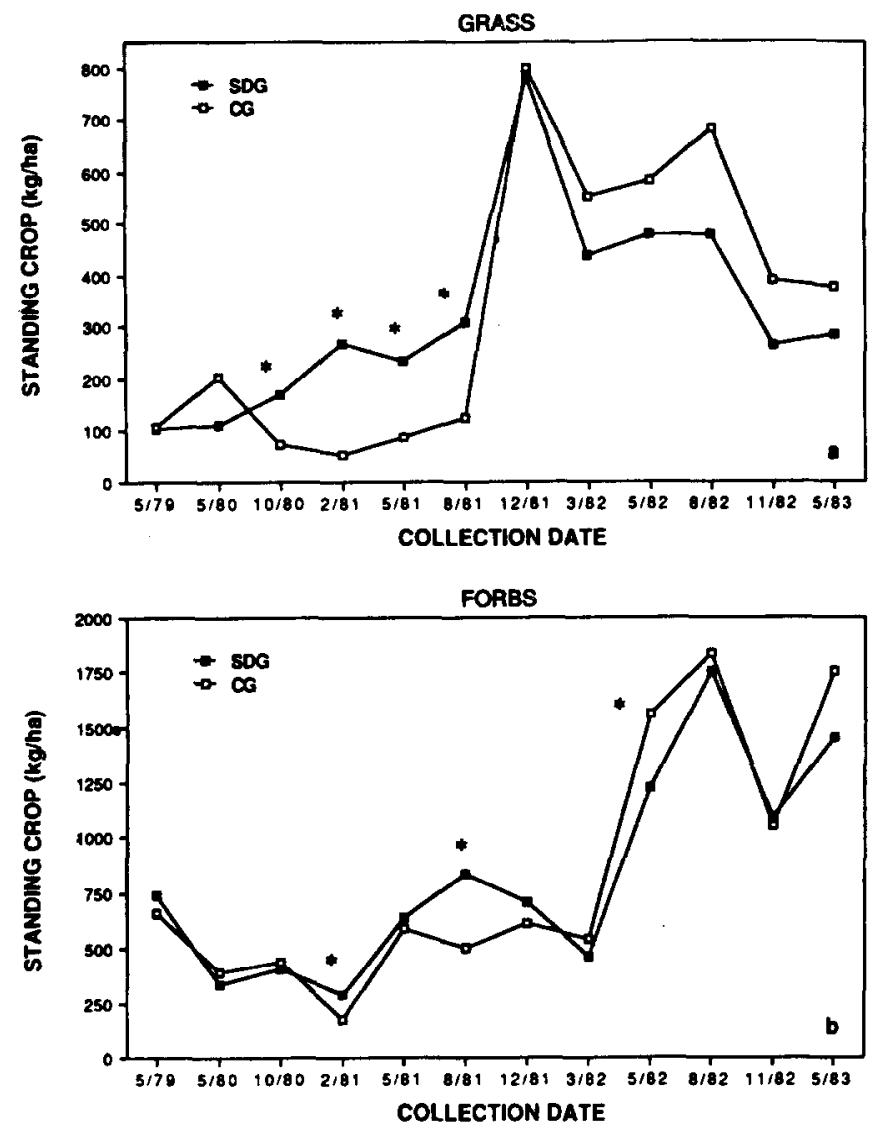

Fig. 1. Standing crop biomass of grass and forbs under continuous and short duration grazing. Lubbock County. Texas. An asterisk (")denotes differences $(P<0.05)$ between case studies.

Table 2. Standing crop biomass of major grase epecies under continuous and short durntion graxing from May samplings 1979-1932, Lubbock County, Texses.

\begin{tabular}{lcccc}
\hline & \multicolumn{4}{c}{ SDG } \\
\cline { 2 - 5 } Species & 1979 & 1980 & 1981 & 1982 \\
\hline Bouteloua gracilis & $45.9 \mathrm{a}$ & $95.1 \mathrm{a}$ & $90.3 \mathrm{a}$ & $273.6 \mathrm{~b}$ \\
Buchloe dactyloides & $3.9 \mathrm{a}$ & $6.0 \mathrm{a}$ & $10.4 \mathrm{a}$ & $43.0 \mathrm{~b}$ \\
Panicum oblusum & $21.9 \mathrm{a}$ & $6.5 \mathrm{a}$ & $1.1 \mathrm{a}$ & $25.9 \mathrm{a}$ \\
Sporobolus cryptandrus & $0 \mathrm{a}$ & $4.0 \mathrm{a}$ & $2.0 \mathrm{a}$ & $42.7 \mathrm{~b}$ \\
Aristida purpurea & $11.4 \mathrm{ab}$ & $0 \mathrm{a}$ & $13.8 \mathrm{ab}$ & $57.1 \mathrm{~b}$ \\
Bothriochloa saccharoides & $11.7 \mathrm{a}$ & $0 \mathrm{a}$ & $70.0 \mathrm{a}$ & $31.7 \mathrm{a}$
\end{tabular}

\begin{tabular}{|c|c|c|c|c|}
\hline \multirow[b]{2}{*}{ Species } & \multicolumn{4}{|c|}{ CG } \\
\hline & 1979 & 1980 & 1981 & 1982 \\
\hline $\begin{array}{l}\text { Bouteloua gracilis } \\
\text { Buchloe dactyloides } \\
\text { Panicum obtusum } \\
\text { Sporobolus cryptandrus } \\
\text { Aristida purpurea } \\
\text { Bothriochloa saccharoides }\end{array}$ & $\begin{array}{r}45.1 \mathrm{a} \\
4.0 \mathrm{a} \\
58.9 \mathrm{a} \\
0 . \mathrm{a} \\
0 \mathrm{a} \\
0.1 \mathrm{a}\end{array}$ & $\begin{aligned} 154.8 \mathrm{a} \\
13.0 \mathrm{a} \\
13.0 \mathrm{a} \\
23.6 \mathrm{a} \\
0 \mathrm{a} \\
0 \mathrm{a}\end{aligned}$ & $\begin{array}{rl}64.6 \mathrm{a} \\
14.1 \mathrm{a} \\
0.1 \mathrm{a} \\
10.1 \mathrm{a} \\
00 & \mathrm{a} \\
0 & \mathrm{a}\end{array}$ & $\begin{array}{r}359.2 \mathrm{~b} \\
68.6 \mathrm{~b} \\
5.1 \mathrm{a} \\
81.1 \mathrm{~b} \\
26.3 \mathrm{~b} \\
37.3 \mathrm{~b}\end{array}$ \\
\hline
\end{tabular}

- $\mathrm{Y}$ Year means followed by a different letter are significantly different $(P<0.05)$.

relatively unpalatable species, was responsible for much of the difference in standing crop between CG and SDG (Table 2). Again, no differences $(P>0.05)$ between CG and SDG were observed in standing crop of forbs by the end of the second year. 


\section{Third Year}

Because of poor performance of individual animals on SDG the prior year, stocking rate was reduced for the third year to $\mathbf{8 . 9}$ ha/AU. Average daily gains for the third year were similar for both SDG and CG (0.33 kg/day vs. $0.37 \mathrm{~kg} /$ day, respectively) (Table 1$)$. Because of the higher stocking rate, SDG produced more gain/ha $(P<0.05)$ the $C G 22.6 \mathrm{~kg} /$ ha vs $16.9 \mathrm{~kg} / \mathrm{ha}$, respectively.

Standing crop of grasses was greater $(P<0.05)$ for SDG compared to CG in May and August of 1981 (Fig. 1). By March 1982, grass biomass on SDG fell below that of CG. Aristida purpurea and Bothriochloa saccharoides again were responsible for greater standing crop on SDG early in year 3 (Table 2). Standing crop of forbs in August 1981 was greater $(P<0.05)$ on SDG than CG (Fig. 1).

\section{Fourth Year}

Animal performance in the fourth year was measured April through November 1982. For this period, ADG for both case studies was similar at $0.55 \mathrm{~kg} /$ day for SDG steers and $0.61 \mathrm{~kg} /$ day for CG steers (Table 1). Weight gains on SDG were slightly less than those of CG for most months during the fourth year. Steers under CG gained 30\% more than the SDG steers in June and $40 \%$ more in August; these differences were significant $(P<0.05)$. Gain/ ha was $25 \%$ greater $(P<0.05)$ on SDG compared to CG again because of higher stocking on SDG (Table 1). These values are similar to those from the previous year.

From May 1982 until May 1983, the trend was for grass standing crop on CG to be greater than on SDG (Fig. 1). This trend in grass standing crop probably reflects the lighter stocking rate under $C G$.

\section{Floristic Changes}

When May standing crop estimates were analyzed across years within $C G$ and SDG, differences $(P<0.05)$ among years occurred for most plant species on both case studies. Because each species from both CG and SDG responded similarly (Table 2), increases and declines in biomass over the 4 years seemed to be more closely related to rainfall than grazing.

\section{Diet Composition and Quality Botanical Composition}

Twenty-two grass species and $\mathbf{3 7}$ forb species were identified in steer diets on SDG. Twenty-one grass species and 34 forb species were identified in diets on CG. Twenty forb and grass species made up 94 and $86 \%$ of the SDG and CG steer diets, respectively. Although the same 20 species comprised the majority of the diet on both SDG and CG, proportions of individual species varied greatly. Four species (Bouteloua gracilis, Buchloe dactyloides, Panicum obtusum, and Sporobolus cryptandrus) in different proportions, made up 78 and $80 \%$ of the grass component of the diets on SDG and CG, respectively (Pitts 1983). Prevalent forbs in the diet on both SDG and CG were Kochia scoparia, Sphaeralcea coccinea, and Zinnia grandiflora.

Bouteloua gracilis was greater in standing crop biomass than any other grass species on both areas. Under CG, Bouteloua gracilis made up $20 \%$ of the diet across the growing season, vs. only $13 \%$ of the diets on SDG for the same period (Pitts 1983). Availability of Buchloe dactyloides was less than that of Bouteloua gracilis on both areas, but animals selected more heavily for this species than any other. Buchloe dactyloides made up 21 and $23 \%$ of the diets on SDG and CG, respectively (Pitts 1983).

SDG appeared to delay steer use of Panicum obtusum one month later than on CG, thereby extending the grazing period for this plant. The proportion in the diet reached $28 \%$ under SDG in early June compared to only $5 \%$ on CG (Pitts 1983). Ingestion of this species was minimal throughout the remainder of the growing season on both areas. Sporobolus cryptandrus provided $15 \%$ of the diet of the CG animals throughout the growing season, and $8 \%$ for SDG animals (Pitts 1983).
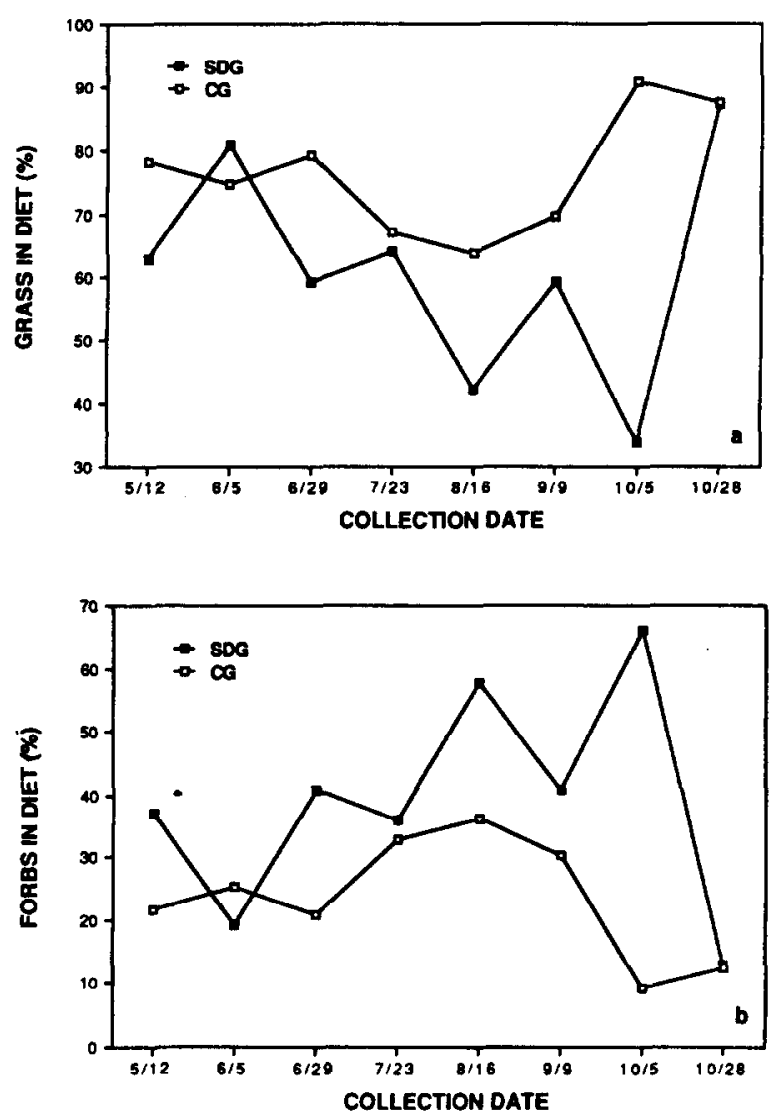

Fig. 2. Percentage of grass and forbs in steer diets under continuous and short duration grazing in 1982, Lubbock County, Texas. Collection date refers to the date when 6-day collections were initiated.

Forb consumption was $15 \%$ greater on SDG than on CG when averaged over the growing season (Fig. 2). The trend for greater a vailability of grass species on CG compared to SDG (Fig. 1) indicates that high forb consumption under SDG was probably because of lack of availability of preferred grasses rather than a preference for forbs. Kochia scoparia contributed most to this difference. Diets on SDG contained $15 \%$ and $27 \%$ Kochia scoparia in May and June, respectively, compared to $1 \%$ and $5 \%$ for the same months for steers under CG (Pitts 1983).

Browse consumption was minimal $(<2 \%)$ for both CG and SDG throughout the growing season (Pitts 1983). Browse species occurring in the diet were Acacia species, Prosopis glandulosa, and Artemisia filifolia.

\section{Chemical Composition}

Crude protein and digestible organic matter in the diets declined from spring through fall on both CG and SDG (Fig. 3). There were no differences $(P>0.05)$ between CG and SDG in crude protein or digestible organic matter concentration of steer diets averaged over the entire growing season. Crude protein values of around $16 \%$ in steer diets occurred in May for both CG and SDG, coinciding with early spring growth (Fig. 3). By late July, dietary crude protein declined to a bout $9 \%$ and dropped to $7 \%$ by late October (Fig. 3). A seasonal decline also occurred in digestible organic matter for both CG and SDG (Fig. 3). High levels of forbs in the diet on both SDG and CG coincided with low values of digestible organic matter (Figs. 2 and 3).

\section{Discussion and Conclusions}

At equal stocking rates, animal performance on SDG and CG were the same. These results are similar to those reported by Jung et al. (1984) and Hart et al. (1986). Stcer gains on SDG were 

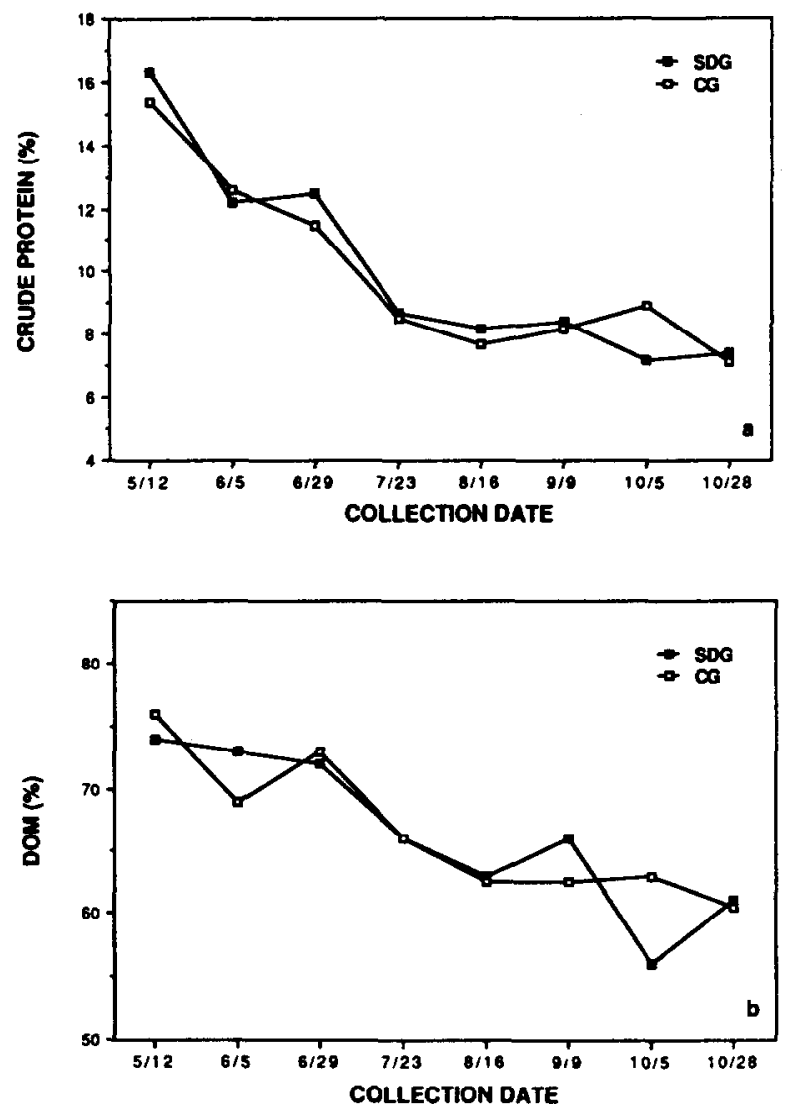

Fig. 3. Crude protein and digestible organic matter (DOM) in steer diets under consinuous and short duration grazing in 1982, Lubbock County, Texas. No differences $(\mathrm{P}<0.05)$ were detected between case studies. Collection date refers to the date when 6-day collections were initiated.

generally less than those of CG during the last 3 years of study when stocking rate of SDG was at 2 times or 1.5 times that of CG. Since stocking was not increased under CG it is not known if decreases in animal performance under SDG were because of increased stocking or inherent effects of SDG itself. Other studies have indicated that individual animal performance will decline with increased stocking under SDG (Reese 1986, Gammon 1984, and Heitschmidt 1986) but similar decreases in steer gains have been observed when stocking under CG has been increased (Hart et al. 1986). It appears that improvement in grazing distribution must be obtained from SDG before increases in stocking rate can be achieved without decline in animal performance. In this study, distribution was not improved and poor animal performance under SDG is attributed to stocking rate.

Diet quality, in the fourth year of grazing, was similar under SDG and CG, indicating that SDG did not increase or decrease forage quality. Taylor et al. (1980) reported similar results from SDG and Merrill systems when dietary crude protein and digestible organic matter were determined. This further indicates that decreases in animal performance were related to stocking rate and ultimately forage ability.

Standing crop of forage was low on both CG and SDG during the first two years of the study because of low rainfall. Greater standing crop on SDG than CG in year 2 was attributed to 2 relatively unpalatable forage species. In the last 2 years of the trial when adequate rainfall occurred, forage availability was generally less under SDG. Forage availability has also decreased with increased stocking under SDG in other studies (Heitschmidt 1986). However, Kirby et al. (1986) reported similar forage disappearance under CG and SDG with SDG stocked 75\% heavier than CG.
Changes in standing crop of different grass species did occur over the 4-year study but changes were similar for both CG and SDG. Short duration grazing did not increase or decrease range condition compared to CG. It does not appear that stocking rates can be increased as a result of improved range condition through use of SDG. Hart et al. (1986) reported that SDG had no significant effect on range condition compared to $C G$ after 4 years. Denny et al. (1977) claimed that after 3 years under SDG, there was no indication that stocking rates could be increased with any range improvement under SDG. Gammon (1984) also indicated that there was no difference in species composition with SDG and "less intensively" managed systems over time.

In this study, SDG did not increase standing crop biomass, range condition, animal performance, or improve diet quality over CG on the Texas High Plains. The slight negative effects of SDG are attributed to greater stocking rates on the SDG system.

\section{Literature Cited}

Association of Official Agricultural Chemists. 1970. Official methods of analysis. (11th ed.). Ass. Off. Agr. Chem. Washington, D.C.

Conniffe, D. 1976. Comparison of between and within herd variance and grazing experiments. Irish J. Agr. Res. 15:39-46.

Denny, R.P., and D.L. Barnes. 1977. Trials of multi-paddock grazing systems on veld. 3. A comparison of 6 grazing procedures at 2 stocking rates. Rhod. J. Agr. Res. 15:129-142.

Denny, R.P., D.L. Barnes, and T.C.D. Kennan. 1977. Trails of multipaddock grazing systems on veld. 1. An exploratory trial of systems involving 12 paddocks and 1 herd. Rhod. J. Agr. Res. 15:11-23.

Gammon, D.M. 1984. An appraisal of short duration grazing as a method of veld management. Zimbabwe Agr. J. 81:59-64.

Hart, R.H., G.E. Schuman, M.J, Samuel, and M.D. Smith. 1986. Timecontrolled grazing research in Wyoming. p. 73-82. In: (J.A. Tiedeman, Ed.) Short duration grazing. Washington State Univ., Pullman.

Heltechmidt, R.K. 1986. Short duration grazing at the Texas Experimental Ranch. p. 91-102. In: (J.A. Tiedeman, Ed.) Short duration grazing. Washington State Univ., Pullman.

Heitechmidt, R.K., D.L. Price, R.A. Gordon, and J.R. Frasure. 1982 . Short duration grazing at the Texas Experimental Ranch: Effects on above ground net primary production and seasonal growth dynamics. J. Range Manage. 35:367-374.

Heltschmidt, R.K., J.R. Frasure, D.L. Price, and L.R. Rittenhouse. 1982 b. Short duration grazing at the Texas Experimental Ranch: I. Weight gains of growing heifers. J. Range Manage. 35:375-379.

Juns, H.G., R.W. Rice, and L.J. Koons. 1984. Comparison of heifer weight gains and forage quality for continuous and short duration grazing systems. J. Range Manage. 38:144-148.

Kirby, D.R., M.F. Peasin, and G.K. Clamby. 1986. Disappearance of forage under short duration and seasonlong grazing. J. Range Manage. 39:496-499.

Nieholas, G. 1976. Grazing trials. Farmers Weekly, July 21. p. 13-15.

Pitts, J.S. 1983. Cattle and vegetation response to short duration and continuous grazing. M.S. Thesis. Texas Tech Univ., Lubbock.

Reese, P.E. 1986. Short duration grazing research and case studies in Nebraska. p. 39-71. In: (J.A. Tiedeman, Ed.) Short duration grazing. Washington State Univ., Pullman.

Savory, A., and S. Parsons. 1980. The Savory grazing method. Beef Cattle Sci. Handbook, Agr. Services Found., Clovis, Calif. 17:215-221.

Soil Conservation Service. 1979. Soil survey Lubbock County, Texas. U.S. Dep. Agr. Soil Conservation Service.

Sparks, D.R., and J.C. Malechek. 1968. Estimating percentage dry-weight in diets using a microscope technique. J. Range Manage. 21:264-265.

Steel, R.G.G., and J.H. Torrie. 1960. Principles and procedures of statistics. McGraw-Hill Book Company, Inc., New York.

Taylor, C.A., M.M. Kothmann, L.B. Merrill, and D.P. Elledge 1980. Diet selection by beef cattle under high-intensity low-frequency, shortduration, and Merrill grazing systems. J. Range Manage. 33:428-434.

Van Soest, P.J. 1970. Chemical basis for the nutritional evaluation of forages. Proc. Nat. Conf. on Forage Qual. Eval. and Util., Lincoln, Neb., 1969. p. U1-U19. 